\title{
Effect of Educational Package for Postpartum Women on Improving Sexual Quality of Life
}

\section{Safaa Abdelaty Goniem ${ }^{1}$, Mohammed Abdel Salam Mohamed ${ }^{2}$, Eman Abdelhakam ${ }^{3}$, Rehab Soliman AbdElAliem ${ }^{4}$}

(1) Clinical Instructor in Technical Nursing Institute ,Faculty of Nursing, Benha University, (2) Obstetrics and Gynecology Director of Banha University Hospitals- Faculty of Medicine Benha University, and (3,4) assistant professor of Obstetrics and Woman's Health Nursing, Faculty of Nursing, Benha University, Benha, Egypt

\begin{abstract}
Background: Women's sexual health is a vital and important part of life at any age. The high prevalence of sexual disorders postpartum significantly impact quality of life. Aim: the present study aimed to examine effect of educational package for postpartum women on improving sexual quality of life. Design: Aquasi-experimental study (pre and posttests, non-andomized study) was utilized to fulfill the aim of this study. Setting: Antenatal Outpatient Clinic affiliated to Benha University Hospitals. Sample: A purposive sample was selected according to inclusion criteria .The sample consisted of 200 postpartum women fulfill the criteria of the current study according to the census of the last 6 months (2018). Tools: Data collected through three main tools structured interviewing questionnaire, Female Sexual Function Index and The sexual quality of life-female questionnaire Results: the present study showed a highly statistically significant differences between control and study groups related to sexual domains and dyspareunia data at postintervention phase. Conclusion: There was a positive statistically significant correlation between pre and post intervention, as regards total knowledge and total sexual quality of life. . Recommendations: - Provide counseling, training program about sexual nursing care intervention during postpartum period for nurses working in different health care setting.
\end{abstract}

Key words: Educational package, Postpartum, Sexuality, Sexual quality of life.

\section{Introduction}

Pregnancy and childbirth are major events in marital life, which exert extreme physical, emotional, and social effects on women, thereby inducing changes in the sexual function of this population. These periods are transient in the lives of women. The important goals of reproductive health for women in the postpartum period include enjoying sexual relationships, having a healthy newborn, becoming a mother, and establishing a marital relationship full of emotional and spiritual satisfaction ( Banaei et al., 2018).

Sexuality is an essential component of human life with important effects on physical and psychological health as well as Quality Of Life (QOL). Female sexual dysfunction, a general term including pain at intercourse and desire, arousal, or orgasm problems, is quite common. Female sexual dysfunction is influenced by numerous factors such as vaginal delivery, genital surgery, advanced age and hormonal changes, endocrine disorders, psychiatric and psychological dysfunctions as ; depression, anxiety, distraction, negative body image, sexual abuse, and emotional neglect (Caruso and Monaco, 2019).

Female Sexual Dysfunction (FSD) is defined as disorders of sexual desire, arousal, 
orgasm, and sexual pain, which lead to personal distress. The etiology of sexual dysfunction is frequently multifactorial as it relates to general physical and mental wellbeing, quality of relationship, past sexual functioning, social class, education, employment, life stressors, personality factors, the presence of a sexual partner, and partner's age and health. FSD is highly prevalent in Egypt, orgasm and desire scores were the most affected domains (Nazanin et al., 2018).

Nurse is an important member of the health care team to counsel the women in the sensitive and highly charged area of human sexuality. Sexuality and sexual health problems are challenging areas for nurses so, care should be approached in a way that respect women confidentiality and sensitively explores women's needs. Nursing interventions (education and counseling on sexuality) are used to assist women to resolve their sexual problems (Chow et al., 2016).

\section{Aim of the study}

The aim of this study is to examine effect of educational package for postpartum women on improving sexual quality of life.

\section{Research Hypothesis}

The educational package for postpartum women will be effective on improving sexual quality of life.

\section{Significance of the study}

Sexual dysfunction reflects a chain of psychiatric experiences of individuals and couples, which emerges as a problem or dysfunction of sexual desire, sexual arousal or orgasm, or pain during intercourse. There is a lack of professional awareness in recognizing this condition, thus leaving it underexplored. It is important for healthcare professionals to recognize this problem at primary care level because effective basic treatment for most female sexual dysfunction can be successfully provided by primary care physicians (Zhang et al., 2017).

\section{Subjects and method}

\section{Study design:}

Aquasi-experimental design (pre and posttests, non-randomized study) was utilized to fulfill the aim of this study.

\section{Study Setting:}

The study was conducted in the outpatient clinic of Obstetrics \&Gynecology department at Benha University Hospital.

\section{Sample type:}

A Purposive sample.

\section{Sample size:}

A total 200 postpartum women fulfill the criteria of the current study

\section{Sample technique:}

The researcher visited the study setting, introduced herself to women and explained the aim of the study briefly to those who fulfilled the inclusion criteria and agree to participate in the study for a period of 6 months were included in the study. The visit was repeated 3times/week from 9-12 pm until the predetermined size of sample was completed.

\section{Inclusion criteria}

The cases selected according to the following;

1. Women at child bearing age (18-40) years.

2. During the first 6 month after delivery

3. women immediately after postpartum

4. Free from medical, gynecological diseases or not take any medication that lead to sexual dysfunction.

\section{Tools of data collection}

Three main tools were utilized for data collection:-

Tool (I): Structured interviewing questionnaire :

The researcher designed it after reviewing related literatures under guidance of 
supervisors and it was written in simple Arabic language in the form of close and open- ended questions. It consisted of five parts:

Part (1): Socio demographic characteristics of the studied women and their husbands such as;( age, educational level, occupation, residence, monthly income weight, height, body mass index and type of jop ,etc......)

Part (2): Gynecologic and sexual history of the studied women such as; history of circumcision, onset of menstruation after delivery, time of resumption, frequency of sexual intercourse after delivery, calm environment during intercourse and problem during sexual intercourse before and during pregnancy.

Part (3): Husband information such as; occupational status, age, and suffering from chronic disease.

Part (4): Current history of postpartum period which include; date and type of delivery, pain during intercourse after delivery, Performance of episiotomy during labor, Episiotomy pain during intercourse contraceptive method, breast-feeding and Neonatal complain.

Part (5): Knowledge of studied women regarding sexuality problems Sexual problems history of the studied women included: receiving information about sexuality, source of information. The researcher designed it after reviewing related literatures (Mansour et al., 2014, Lobez et al., 2018).

Total Scoring system of knowledge:

Poor -----------<60\% of total knowledge score Average ----60-75\% of total knowledge score Good ----------> 75\% of total knowledge score

Tool II -: Female Sexual Function Index The Female Sexual Function Index (FSFI):

A brief questionnaire to measure sexual functioning. Designed by (Rosen et al., 2000) for English form to evaluate sexual function domains, composed of 19 items and divided into six domains. The Female Sexual Function Index is translated into simple Arabic language to suit Egyptian culture. The Arabic FSFI is a validated, reliable, and locally accepted tool for use in the assessment of female sexual function in the Egyptian population by (Wiegel et al., 2005) .

Total Scoring system of Female Sexual Function Index

Low sexual function ------<60\% of total sexual function score.

Moderate sexual function ------ 60-75\% of total sexual function score.

High sexual function ------- $<60 \%$ of total sexual function score.

III) The sexual quality of life-female (SQOL-F) questionnaire: It was developed by (Symonds et al., 2017). It is a valid and reliable instrument for evaluation of female SQOL it includes sexual self-esteem, emotional and relationship issues. It consists of 18 items and each item is rated on a sixpoint response ranged from (completely agree to completely disagree).

Scoring system: The response categories scored from 1 to 3 score. Higher score indicates better female sexual quality of life. In addition, total score was converted into total percentage and graded as the following; if percentage of the total score more than $75 \%$ considered good, if percentage of the total score from $60-75 \%$ considered average, and considered poor if the percentage of total score is less than $60 \%$.

\section{Tool Validity:}

The validity of questionnaire was reviewed by 3 jury experts in the field of obstetrics \& woman health nursing and of Obstetrics and Gynecology Medicine at Benha University to ascertain clarity, relevance, comprehensiveness, and applicability of tools. 


\section{Tool reliability}

Reliability was done by Cronbach's alpha coefficient to assess the reliability that indicated that each of the two tools which consisted of relatively homogenous items as indicated by the moderate to high reliability of each tool. Was $\alpha=0.851$.

\section{Ethical Considerations:}

Ethical aspects were considered before implementation of the study as the following:-

○ An official permission from the study setting was obtained for the fulfillment of the study.

- The aim of the study was explained to each woman before applying the tools at the beginning of interview and throughout the study to gain their confidence and trust.

- The researcher obtains oral consent from each woman to participate in the study and withdraw when she needs without obligation.

\section{Pilot study}

The pilot study was carried out before starting data collection. It was done to estimate the time required for completing the sheets and to check the simplicity, clarity, applicability and feasibility of the developed tools. The pilot study was conducted on $10 \%$ of the total sample ( 20 women). There were modifications done. Thus, women involved in the pilot study were not included in the study.

\section{Field work}

The study carried out for 6 months from the period of beginning of august (2019) to the end of January (2020).

Assessment phase: (visit one).This phase encompassed interviewing women to collect baseline data. At the beginning of interview the researcher introduced herself, greeted each women, explained the aim of the study, scheduled times and frequency of counseling sessions to selected women to assure adherence to selected interventions. The researcher took oral consent from women to participate in the study.

\section{Planning Phase}

The program was conducted to examine the effect of educational package for postpartum women on improving sexual quality of life. The researcher and participants attended data collection site for three times/ week from Saturday to Tuesday with alternation. The duration of the educational program lasted 2 months. Program was classified into 6 sessions each session was planned to provide specific information about puerperium period, dyspareunia (symptoms, causes, and management), sexual relationship afterbirth, factors affecting the willingness of women to have sexual relationship again. Instruction for improving sexual quality of life using booklet as a guideline.

Implementation Phase: the educational sessions will conduct in Obstetrics and Gynecological Outpatient Clinic at Benha University Hospital. The researcher visit the above-mentioned setting from 9.00 am to $12.00 \mathrm{pm}$, three days per week (Saturday, Monday and Tuesday).

\section{Evaluation Phase:}

After one and half months of completion of the program the post test was applied to assess and evaluate women's sexual quality of life and sexual function through use female sexual quality of life. Finally the researcher compared pretest and posttest results to evaluate the effectiveness of the educational package implementation.

\section{Statistical analysis:}

Data were verified prior to computerized entry. The Statistical Package for Social Sciences (SPSS version 22) was used followed by data tabulation and analysis. Descriptive statistics were applied (e.g., mean, standard deviation, frequency and 
percentages). In addition, test of significance and Pearson correlation.

\section{Results}

Table (1) shows that less than half $(47 \%)$ of the studied women were in age group $<20$ years with Mean \pm SD 29.85 \pm 7.62 , more than half $(51.5 \%)$ have secondary education, while two third $(60 \%)$ are house wife, $57 \%$ have hard work. Less than three quarters $(72 \%)$ live in urban areas while more than half $(57 \%)$ of them don't have enough monthly income.

Table (2) shows that more than half (54\%) of the studied women's time of delivery was 3-4 months. Also more than half (56\%) of them were cesarean delivery while more than three quarter $(79 \%)$ of studied women feel pain during intercourse in postpartum period. Two thirds $(66 \%)$ of the studied women were performed breast feeding and one third (39\%) of them use lobe as contraceptive method.

Table (3) showed highly statistical significant difference between pre and post intervention $(\mathrm{P}<0.001)$, as regards the mean total score of sexual function domains.

Table (4) shows a highly statistical significant difference between pre and post intervention $(\mathrm{P}<0.001)$, as regards the mean total score of women's sexual quality of life domains.

Table (5) reveals appositive statistical significance correlation between pre and post intervention, as regards total knowledge score and total sexual health. Also there were appositive statistical significance correlation between pre and post intervention, as regards total knowledge and total sexual quality.

Table (1): distribution of personnel characteristics of the studied women $(n=200)$

\begin{tabular}{|l|l|l|}
\hline $\begin{array}{l}\text { Personnel } \\
\text { characteristics }\end{array}$ & Number & $\%$ \\
\hline Age (years) & 94 & 47.0 \\
\hline$<25$ & 46 & 23.0 \\
\hline $25: 30$ & 12 & 6.0 \\
\hline $31: 35$ & 36 & 18.0 \\
\hline $36: 40$ & 12 & 6.0 \\
\hline$>40$ & \multicolumn{2}{|l|}{} \\
\hline Mean \pm SD & $\mathbf{2 9 . 8 5} \pm 7.62$ \\
\hline Educational level & 23.0 \\
\hline Primary education & 46 & 51.5 \\
\hline Secondary education & 103 & 25.5 \\
\hline University education & 51 & 60.0 \\
\hline Occupation & 120 & 40.0 \\
\hline House wife & \multicolumn{2}{|l|}{} \\
\hline Employee & 43.0 \\
\hline Type of job & 86 & 57.0 \\
\hline Office work & 114 & 72.0 \\
\hline Hard work & 144 & 28.0 \\
\hline Residence & 43.0 \\
\hline Urban & 57.0 \\
\hline Rural & 56 & \\
\hline Monthly income & 86 & \\
\hline Enough & 114 & \\
\hline Not enough & \\
\hline
\end{tabular}


Table (2): Distribution of current obstetric history of the studied women $(n=200)$.

\begin{tabular}{|c|c|c|}
\hline Current obstetric history & Number & $\%$ \\
\hline \multicolumn{3}{|l|}{ Time of delivery } \\
\hline $1-2$ months & 64 & 32.0 \\
\hline $3-4$ moths & 108 & 54.0 \\
\hline 5-6 months & 28 & 14.0 \\
\hline \multicolumn{3}{|l|}{ Type of delivery } \\
\hline Normal delivery & 88 & 44.0 \\
\hline Cesarean delivery & 112 & 56.0 \\
\hline \multicolumn{3}{|c|}{ Pain during intercourse in postpartum period } \\
\hline Yes & 158 & 79.0 \\
\hline No & 42 & 21.0 \\
\hline \multicolumn{3}{|c|}{ Performance of episiotomy during labor } \\
\hline Yes & 90 & 45.0 \\
\hline No & 110 & 55.0 \\
\hline \multicolumn{3}{|c|}{ Episiotomy pain during intercourse } \\
\hline Yes & 88 & 44.0 \\
\hline No & 112 & 56.0 \\
\hline \multicolumn{3}{|l|}{ Neonatal complain } \\
\hline Yes & 70 & 35.0 \\
\hline No & 130 & 65.0 \\
\hline \multicolumn{3}{|l|}{ Breast feeding } \\
\hline Yes & 132 & 66.0 \\
\hline No & 68 & 34.0 \\
\hline \multicolumn{3}{|l|}{ Contraceptive method } \\
\hline Safe period & 22 & 11.0 \\
\hline Lobe & 78 & 39.0 \\
\hline Injection & 68 & 34.0 \\
\hline Tablet & 32 & 16.0 \\
\hline
\end{tabular}

Table (3): Distribution of the studied women total sexual function domain at pre and postintervention $(\mathbf{n}=\mathbf{2 0 0})$.

\begin{tabular}{|c|c|c|c|c|}
\hline Domain & $\begin{array}{l}\text { Pre- } \\
\text { intervention }\end{array}$ & $\begin{array}{l}\text { Post } \\
\text { intervention }\end{array}$ & $\begin{array}{ll}\text { Paired } \\
\text { test }\end{array}$ & P value \\
\hline & Mean \pm SD & \begin{tabular}{|l|} 
Mean \pm SD \\
\end{tabular} & & \\
\hline Desire & $3.3900 \pm 1.5692$ & $6.8900 \pm 1.9116$ & 17.657 & $\begin{array}{l}<0.001 \\
* *\end{array}$ \\
\hline Arousal ( during sexual activity) & $6.9900 \pm 2.4679$ & $14.1900 \pm 2.765$ & 22.214 & $\begin{array}{l}<0.001 \\
* *\end{array}$ \\
\hline $\begin{array}{|lrr|}\begin{array}{l}\text { Lubrication( during } \\
\text { activity) }\end{array} & \text { sexual } \\
\end{array}$ & $6.2100 \pm 1.0569$ & $15.0000 \pm 3.171$ & 25.829 & $\begin{array}{l}<0.001 \\
* *\end{array}$ \\
\hline Orgasm( during sexual activity) & $3.6500 \pm 1.0480$ & $8.3800 \pm 1.195$ & 26.077 & $\begin{array}{l}<0.001 \\
* *\end{array}$ \\
\hline \begin{tabular}{|lll}
$\begin{array}{l}\text { Satisfaction( } \\
\text { activity }\end{array}$ & during & sexual \\
\end{tabular} & $5.9400 \pm 1.8302$ & $16.9400 \pm 2.159$ & 39.139 & $\begin{array}{l}<0.001 \\
* *\end{array}$ \\
\hline Pain & $\begin{array}{l}12.3900 \pm 2.196 \\
8\end{array}$ & $6.4300 \pm 2.6448$ & 21.627 & $\begin{array}{l}<0.001 \\
* *\end{array}$ \\
\hline Total sexual function & $38.5700 \pm 4.716$ & $67.8300 \pm 6.141$ & 41.543 & $\begin{array}{l}<0.001 \\
* *\end{array}$ \\
\hline
\end{tabular}


Table (4): Distribution of the studied women total sexual quality domains at pre and postintervention $(\mathbf{n}=\mathbf{2 0 0})$.

\begin{tabular}{|l|l|l|l|l||}
\hline Domain & $\begin{array}{l}\text { Pre- } \\
\text { intervention }\end{array}$ & $\begin{array}{l}\text { Post } \\
\text { intervention }\end{array}$ & $\begin{array}{l}\text { Paired t } \\
\text { test }\end{array}$ & P value \\
\cline { 2 - 4 } & Mean \pm SD & Mean \pm SD & & \\
\hline Psychosexual Feelings & $13.9000 \pm 3.0500$ & $32.9300 \pm 1.6096$ & -59.029 & $<0.001^{* *}$ \\
\hline $\begin{array}{l}\text { Sexual and Relationship } \\
\text { Satisfaction }\end{array}$ & $10.8700 \pm 2.1772$ & $21.8000 \pm .86457$ & -50.788 & $<0.001^{* *}$ \\
\hline Self-Worthlessness & $6.1200 \pm 1.38739$ & $13.5500 \pm .80873$ & -46.159 & $<0.001^{* *}$ \\
\hline Sexual Repression & $5.6800 \pm 2.30450$ & $14.3900 \pm .99387$ & -38.890 & $<0.001^{* *}$ \\
\hline Total sexual quality of health & $36.5700 \pm 4.5732$ & $82.6700 \pm 2.5067$ & -90.923 & $<0.001^{* *}$ \\
\hline
\end{tabular}

Table (5): Correlation between studied women total knowledge score and total sexual health and total sexual quality at pre and post-intervention

\begin{tabular}{|c|c|c|c|c|c|c|c|c|c|}
\hline \multirow{3}{*}{\multicolumn{2}{|c|}{ Variables }} & \multicolumn{4}{|c|}{ Total sexual health } & \multicolumn{4}{|c|}{ total sexual quality of life score } \\
\hline & & \multicolumn{2}{|c|}{$\begin{array}{l}\text { Pre- } \\
\text { intervention }\end{array}$} & \multicolumn{2}{|c|}{$\begin{array}{l}\text { Post- } \\
\text { intervention }\end{array}$} & \multicolumn{2}{|c|}{$\begin{array}{l}\text { Pre- } \\
\text { intervention }\end{array}$} & \multicolumn{2}{|c|}{$\begin{array}{l}\text { Post- } \\
\text { intervention }\end{array}$} \\
\hline & & $\mathbf{r}$ & $\begin{array}{l}\text { p- } \\
\text { value }\end{array}$ & $\mathbf{R}$ & p-value & $\mathbf{r}$ & p-value & $\mathbf{R}$ & p-value \\
\hline \multirow{2}{*}{$\begin{array}{l}\text { Total } \\
\text { knowled } \\
\text { ge score }\end{array}$} & \begin{tabular}{|l|} 
Pre- \\
intervention
\end{tabular} & 0.056 & $>0.05$ & - & - & 0.176 & $>0.05$ & - & - \\
\hline & $\begin{array}{l}\text { Post- } \\
\text { intervention }\end{array}$ & - & - & 0.551 & $\begin{array}{l}<0.001 \\
* *\end{array}$ & - & - & $\begin{array}{l}0.62 \\
5\end{array}$ & $\begin{array}{l}<0.001 \\
* *\end{array}$ \\
\hline \multicolumn{5}{|c|}{$\begin{array}{l}\text { Discussion } \\
\text { Postpartum period is recognized as a } \\
\text { vulnerable and stressful period for women } \\
\text { of different cultural backgrounds, } \\
\text { accompanied by significant Social and } \\
\text { individual changes for mothers who have } \\
\text { many new concerns and problems during this } \\
\text { period. Postpartum sexual function is } \\
\text { an important issue for couples, as the first } \\
\text { sexual intercourse is an important step for } \\
\text { couples to form a sincere relationship. } \\
\text { Childbirth contributes to structural and } \\
\text { functional changes in the pelvic floor as } \\
\text { most }\end{array}$} & \multicolumn{5}{|c|}{$\begin{array}{l}\text { Several factors can influence childbirth } \\
\text { related sexual dysfunction, such as parity, } \\
\text { breast feeding, delivery mode, episiotomy, } \\
\text { stress, fatigue and physical and } \\
\text { psychological problems such as } \\
\text { postpartum depression Sexual instinct is one } \\
\text { of man's greatest instincts that influence } \\
\text { his conduct Sexual function, considered part } \\
\text { of women's health, is an essential component } \\
\text { of life and is a multidimensional } \\
\text { phenomenon influenced by many biological } \\
\text { and psychological factors. } \\
\text { dysfunction refers to a chain of psychiatric, } \\
\text { individual, and couple's experiences that } \\
\text { manifests itself as a dysfunction in sexual } \\
\text { desire, sexual excitement, orgasm, and pain } \\
\text { during intercourse (Gutzeit et al ., 2020). } \\
\text { Regarding characteristics of the studied } \\
\text { women, the findings of the present study }\end{array}$} \\
\hline
\end{tabular}


revealed that more than one quarters of the studied women's age $<25$ years old. This may be due to most girls in Egypt married around twenty This finding is nearly similar to Rashad et al ., (2017) who studied the Effect of Mode of Delivery on Postpartum Female Sexual Function in Suez Canal University.

Regarding educational level, occupation and residence the findings of the present study showed that about half of women had secondary education, more than half are house wife and more than two third are life in rural area respectively. This low education level may be the cause for avoiding discussion about sexual issues This finding is nearly similar to Abd El-hakam et al., (2018) who studied the Effect of PLISSIT Model Sexual Counseling Program on Sexual Quality of Life for Postpartum Women and reported that $37.3 \%$ were had middle education, $81.8 \%$ of women were housewives and $70.9 \%$ of studied women were living in rural areas. Also this result is in agreement with Elnashar et al., (2016), who studied female sexual dysfunction in Lower Egypt and denoted that $50 \%$ of the study subjects had secondary education, and about two thirds of them were from rural areas.

Regarding Current obstetric history of the studied women the findings of the present study showed that more than half of women were delivered Caesarean Section. This result in line with Rezaei et al ., (2017) who found type of delivery in (61.3\%) of cases was caesarean. the present study revealed that almost of studied women made episiotomy with vaginal delivery. This finding is In the same line with Leal et al., (2014) who found that almost all the studied participants had one to three children and (80.3\%) of full term vaginal delivery women had episiotomy. From the point of the researcher, several problems associated with caesarean section and episiotomy such as perennial pain and weakness of pelvic floor muscles mainly affect the return to normal sexual life postnatal.

On regard to studied women' postpartum period; Around half of women were in three to fourth month postpartum, similar to Banaei et al., (2016) they conducted a study about " Impact of counseling on sexual intimacy of lactating women" revealed that, mean postpartum duration of studied women was3.56 \pm 1.58 months.

About two third of studied women lactate their children naturally, Breast feeding is a good women attitude as it has many maternal and fet al benefits, so the researcher advice women about the important of exclusive breast feeding up to six months. Breast feeding is known to cause vaginal dryness and decrease libido and contribute to postpartum dyspareunia this due to excessive secretion of prolactin hormone, suppress estrogen and progesterone secretion

This finding consistent with Valadan et al., (2014) who found that the majority of women breastfed their neonates. Also nearly half of women used intra uterine device for contraception. Similar to Mansour et al., (2014) reported that nearly half of women with dyspareunia used intrauterine device as a contraceptive method. Also, supported by Khajehei, (2013) who concluded, that the highest percentage of women were using mechanical methods for contraception. These results were supported by Sok et al ., (2016) who conducted a study of postpartum women's sexual behavior, satisfaction and contraceptive use and reported that 49 percent of women reported using contraceptive methods. 
Current study displayed a highly statistical significant difference of FSFI total score between pre and post intervention phases of women. Total score of sexual function domains was $(38.5700 \pm 4.716)$ and $(67.8300 \pm 6.141)$ respectively at pre- postintervention phases. This result confirmed the achievement of current research hypothesis.

In addition, this result agreed with Mojdeh et al., (2017) who studied" Addressing the Sexual Function of Women During First Six Month After Delivery: Aquasi-Experimental Study" illustrated a statistically significant difference in pre-counseling stage and 4 weeks after counseling in the two groups. Four weeks after consultation, there was a highly statistically significant difference in the mean score of sexual functions between the control and experimental groups.

The results of the present study revealed that there were highly statistical significant differences of the studied women in pre and post intervention regarding mean FSFI six domains and total scores after implementing sexual education Package.

These results is in accordance with Heidari et al., (2017) who studied "Effect of an Educational Intervention on the Sexual Life during postpartum period of Iranian Couples, indicated that there were improvements in the sexual function of women for the study group after sexual education, this probably is attributed to the fact that sexual counseling is one of the most important issues which had positive effect on improving the sexual response and sexual activities of women during postpartum period, this may lead to increase satisfaction and improving the sexual needs of women, reducing pain, and also helping to improve the quality of life during this critical period of their lives.
As regards studied sample sexual quality of life, the current study showed that, there were highly statistical significant differences between women pre and post intervention program regarding all sexual quality of life items $(\mathrm{p}<0.001)$ where, only less percentage of women had good total sexual quality of life pre intervention program, which increased significantly post intervention program. This result was supported by Abd El-hakam et al., (2018) who study the effect of PLISSIT Model Sexual Counseling Program on Sexual Quality of Life for Postpartum Women there were highly statistical significant differences between women before and after the PLISSIT model sexual counseling program regarding all sexual quality of life items $(p<0.001)$ where, only less percentage of women had good total sexual quality of life before PLISSIT model counseling program, which increased significantly after PLISSIT model counseling program.

The present study revealed that there was a positive statistically significant correlation between total total sexual health score and total sexual quality of life. This reflected that improvement in sexual function which resulted in sexual quality of life improvement. In agreement with Rezaei et al., (2017) who reported that, women with higher sexual function scores had significantly better quality of life in all aspects including sexual quality of life.

\section{Conclusion}

Research hypothesis is supported and educational package for postpartum women have positive effect on improving female sexual function and sexual quality of life. There were a highly statistically significant differences in the elements of female Sexual Function index including (desire, arousal, lubrication, orgasm, satisfaction and pain) between studied women at pre and post 
intervention $(\mathrm{P}<0.001)$.More over There was a positive statistically significant correlation between pre and post intervention, as regards total knowledge and total sexual quality of life.

\section{Recommendations}

1- Provide counseling, training program about sexual nursing care intervention during postpartum period for nurses working in different health care setting

2- Use booklet and posters as methods to increase female sexual awareness in outpatient clinics.

3-Activate the pre-marriage counseling program and provide guide line to couples about sexual life.

4- Prepare safe environment in the obstetrics and gynecological outpatient unit to discuss sexual problem with women freely towards sexual problem encountered during the postpartum period.

5-Establish strategies to facilitate the women's understanding and support sexual quality of life through apply this study on a large sample at outpatient clinics.

\section{Further studies:}

1-Nurses should provide education and counseling sessions for postpartum women to promote sexual health and sexual quality of life.

2-Sexual health should be included in the Ministry of Health and Population plan to care for women after childbirth.

3- Study the effect of mode of delivery on postpartum sexual function.

\section{References}

Abd El-hakam M , Refaat, A. Sobhy, D,(2018). Effect of PLISSIT Model Sexual Counseling Program on Sexual Quality of Life for Postpartum7(2): 63-72 .
Banaei, M., Zahrani, Sh., PormehrYabandeh, A., Ozgoli, G., and Azad, M. (2016). Investigating the impact of counselling based on PLISSIT model on sexual intimacy and satisfaction of breastfeeding women, International Journal of Pharmaceutical Research \& Allied Sciences; 5 (3):489-499.

Banaei M, Torkzahrani S, Ozgoli G,et al.(2018). A Addressing the Sexual Function of Women During First Six Month After Delivery:Aquasi Experimental Study Mater Sociomed, 30(2):136.

Caruso, S., and Monaco, C., (2019). Dyspareunia in Women: Updates in Mechanisms and Current/Novel Therapies, Current Sexual Health Reports: 1-12.

Chow, K., Chan, J., Choi, K., and Chan, C.W., (2016). A review of psychoeducational interventions to improve sexual functioning quality of life and psychological outcomes in gynecological cancer patients, Cancer Nursing journal 2016, 39(1):20-31.

Elnashar, A., EL-Dien, I., EL-Desoky, M., Ali, O., El-Sayd, M.,(2016): Female sexual dysfunction in Lower Egypt. International Journal of Obstetrics and Gynaecology, 2016.

Heidari, M., Aminshokravi, F., Zayeri, F., Ali, S (2018). Effect of Sexual Education on Sexual Function of Iranian couples during postpartum period. Journal of Reproduction and Infertility. 2018 Jan-Mar; 19(1): 39-48.

Khajehei, M. (2013). Sexual function of women during the first year after childbirth: Effect of parity (giving birth after the 20th week of pregnancy), depression and 
relationship satisfaction, Doctorate thesis, Curtin University, P. 81.

Leal, I., Lourenço, S., Oliveira, R., Carvalheira, A., and Maroco, J. (2014). Sexual function in women after delivery: Does episiotomy matter?, Health journal; 6 (5): pp. 356-363.

Lobez, L., Gomez, S., Belen, A., Perez, F., and Montserrat, S., (2018). The development and validation of a new postpartum sexual function and dyspareunia assessment tool: The Carol Scale, Midwifery Journal, 58:27-36.

Mansour, S., Shebl, A. , and Waheda, S., (2014). The Effect of Sexual Counseling Program on Pain Level and Sexual Function among Women with Dyspareunia, Journal of Education and Practice ), 5(3):4845-4851.

Mojdeh, B., Sanaz, S., and Hadis, S., (2017). Addressing the Sexual Function of Women During First Six Month After Delivery: Aquasi-Experimental Study, Original Article journal, 10(6): 1763-1769.

Nazanin, R., Arman, A., Kourosh, S., and Reza, V., (2018). Postpartum Sexual Functioning and Its Predicting Factors among Iranian Women, Malays Journal of Medical Science, 24(1): 94-103.

Gutzeit, M., Gali Levy, M., and Lior Lowenstein, M., (2020). Postpartum Female Sexual Function: Risk Factors for Postpartum Sexual Dysfunction Mar; 8(1): 8-13.

Rashad M., Ibrahim, M., Hany M., Safaa M., (2018). The Effect of Mode of Delivery on Postpartum Female Sexual Function in Suez Canal University Hospitals. 21 (2), 120125.
Rezaei, N., Omidi, F., Janani, F., and Azadi, A. (2017). A Study on the Relationship between Sexual Function and Quality of Life in Postpartum Women, Iran, Der Pharmacia Lettre; 9 (7): 10-17.

Rosen, R., Brown, C., Helman, J., Leiblum S., Meston, S., et al., (2000). The Female Sexual Function Index (FSFI): Multidimensional Self-report Instrumental for Assessment Female Sexual Function, Journal of Sex and Marital Therapy, 98 (26): 191-208.

Sok C, Sanders JN, Saltzman HM, et al. (2016): Sexual behavior, satisfaction, and contraceptive use among postpartum women. JMidwif Women's Health, 2016, 61: $158-165$.

Symonds, T., Boolell, M., \& Quirk, F., (2017). Development of a questionnaire on sexual quality of life in women. J Sex Marital Therapy; 31:385-397.

Valadan, M., Shariat, M., Rezaei, Z., Hagholahi, F., Sheikholeslami, G., and Bandegi, P. (2014). A comparative study on quality of life and sexual function after vaginal delivery and Cesarean section, Nurs Pract Today; 1 (4): pp. 176-182.

Wiegel, M., Meston, C., \& Rosen, R. (2005). The Female Sexual Function Index(FSFI): Cross-validation and development of clinical cutoff scores. Journal of Sex \& Marital Therapy, 31, 1-20.

Zhang, C., Tong, J., Zhu, L. , Zhang, L.,Tao, X., et al ., (2017). A PopulationBased Epidemiologic Study of Female Sexual Dysfunction Risk in Mainland China: 
Prevalence and Predictors, Journal of Sexual

Medicine ,14(11):1348-1356.

Zamani, M., Roudsari. R, Moradi. M., et al., (2019). The effect of sexual health counseling on women's sexual satisfaction in postpartum period: A randomized clinical trial. International Journal Reproductive Biomedical. 17(1): 41. 


\title{
تأثير الحزمة التعليمية للنساء بعد الولادة على تحسين نوعية الحياة الجنسية
}

\author{
صفاء عبد العاطي غنيم ، محمل عبد السلام عحم ، إيمان عبد الحكم ، رحاب سليمان عبد العليم
}

تعتبر الصحة الجنسية للمر أة جزء حيوي وهام من الحياة في أي عمر. حيث يؤثر الانتشار المرتفع للاضطر ابات الجنسية بعد الولادة بشكل كبير على جودة الحياة. لذا هدفت هذه الدراسة إلى فحص تأثير الحزمة التعليمية للنساء بعد الو لادة على تحسين نو عية الحياة الجنسية. حيث أجريت الدراسة في عيادة ما قبل الو لادة التابعة لمسنشفيات جامعة بنها على · . ب سيدة بعد الولادة. وأظهرت نتائج الدراسة الحالية فروق ذات دلالة إحصائية عالية بين مجموعات التحكم ومجموعات الدراسة المتعلقة بالمجالات الجنسية وبيانات عسر الجماع في مرحلة ما بعد ـ مرحلة التدخل. وقد خلصت الدراسة الي وجود علاقة ارتباط موجبة ذات دلالة إحصائية بين التدخل قبل وبعد التدخل من حيث المعرفة الكلية والجودة الجنسية الكلية للحياة. كما أوصت الدراسة بضرورة تقديم الاستشار ات و البر امج التدريبية حول تدخل الرعاية التمريضية الجنسية خلال فترة ما بعد الولادة للممرضات العاملات في أماكن الر عاية الصحية المختلفة. 